\title{
How Do Patients Experience Individualized Medicine? \\ A Qualitative Interview-based Study of Gene Expression Analyses in the Treatment of Breast Cancer
}

\author{
Wie erleben Patientinnen individualisierte Medizin? \\ Eine qualitative Interviewstudie zum Beispiel der Genexpressions- \\ analysen bei der Mammakarzinombehandlung
}

Authors

Sebastian Schleidgen ${ }^{1 *}$, Sandra Thiersch ${ }^{2 *}$, Rachel Wuerstlein ${ }^{3,4}$, Georg Marckmann ${ }^{2}$

Affiliations

1 Pflegewissenschaftliche Fakultät, PhilosophischTheologische Hochschule Vallendar, Vallendar, Germany

2 Institut für Ethik, Geschichte und Theorie der Medizin, Ludwig-Maximilians-Universität München, München, Germany

3 Klinik und Poliklinik für Frauenheilkunde und Geburtshilfe, Brustzentrum der Universität München, München, Germany

4 Comprehensive Cancer Center LMU München, München, Germany

Key words

joint decision-making, gene expression analyses, medical benefit, molecular genomic individualization

Schlüsselwörter

gemeinsame Entscheidungsfindung, Genexpressionsanalyse, medizinischer Nutzen, molekulargenetische Individualisierung

received 5.5.2017

revised 27.6.2017

accepted 30.6.2017

Bibliography

DOI https://doi.org/10.1055/s-0043-115396

Geburtsh Frauenheilk 2017; 77: 984-992 @ Georg Thieme Verlag KG Stuttgart · New York | ISSN 0016-5751

\section{Correspondence}

Sandra Thiersch

Institut für Ethik, Geschichte und Theorie der Medizin,

Ludwig-Maximilians-Universität München

Lessingstraße 2, 80336 München, Germany

sandra.thiersch@med.uni-muenchen.de

\section{ABSTRACT}

Introduction In recent years, the hopes and expectations associated with so-called individualized medicine have been the subject of intense debate as has the medical potential of this approach. Questions about the uses of gene expression analyses for decisions on adjuvant systemic treatment options for patients with breast cancer have played a prominent role in this debate. There are a number of empirical studies on the effect of gene expression tests on the therapy decisions of physicians and the potentially conflicted decisions for patients. Very little attention has been paid to how patients perceive such approaches, the extent to which they feel included in the therapy decision, and the expectations they associate with such an approach.

Material and Methods Using qualitative explorative interviews, the study looked at how well patients with breast cancer understood the individualized treatment approaches and examined patients' experiences and expectations with regard to gene expression analyses. The sample consisted of 8 patients who were diagnosed with primary hormone receptorpositive, HER2-negative breast cancer between 2013 and 2014 and who underwent gene expression analyses as part of their adjuvant therapy planning.

Results Patients were found to have a quite realistic view of the benefits of gene expression analyses, although it also became clear that the treatment could also raise false hopes. The statements by the interviewed women also illustrated the necessity of continuing to explore the possibilities and limits to joint decision-making in such complex medical contexts as individualized molecular genomic medicine. And finally, the interviews reflected the hope for individualized treatment in the broadest sense of the word.

Conclusion The results of the study highlight the challenge of taking psychosocial aspects of medical treatment sufficiently into consideration, given the ever increasing options for molecular genomic individualization. 


\section{ZUSAMMENFASSUNG}

Einleitung Die mit der sogenannten individualisierten Medizin verbundenen Hoffnungen und Erwartungen sind seit einigen Jahren ebenso Gegenstand intensiver Debatten wie ihr medizinisches Potenzial. Prominent ist in diesem Zusammenhang die Frage nach dem Nutzen von Genexpressionsanalysen zur Entscheidung über adjuvante Systemtherapieoptionen bei Mammakarzinompatientinnen. Zwar gibt es eine Reihe empirischer Untersuchungen zum Einfluss der Ergebnisse von Genexpressionstests auf ärztliche Therapieentscheidungen sowie möglicherweise auftretende Entscheidungskonflikte bei Patienten. Kaum erforscht wurde bislang allerdings, wie Patienten solche Ansätze wahrnehmen, wie sie sich in entsprechende Therapieentscheidungen einbezogen fühlen und welche Erwartungen sie mit solchen Ansätzen verbinden.

Material und Methoden Vor diesem Hintergrund wurde anhand qualitativ-explorativer Interviews das Verständnis von Brustkrebspatientinnen über individualisierte Behandlungsansätze sowie ihre Erlebnisse und Erwartungen in Bezug auf die Durchführung von Genexpressionsanalysen untersucht. Die Stichprobe bestand aus 8 Patientinnen, bei denen zwi- schen 2013 und 2014 ein primäres, hormonrezeptorpositives, HER-2-negatives Mammakarzinom festgestellt wurde und die sich im Rahmen ihrer adjuvanten Therapieplanung einer Genexpressionsanalyse unterzogen hatten.

Ergebnisse Dabei zeigte sich eine durchaus realistische Auffassung der Möglichkeiten von Genexpressionanalysen, auch wenn deutlich wurde, dass das Behandlungskonzept auch falsche Hoffnungen wecken kann. Die Aussagen der Interviewpartnerinnen verdeutlichten darüber hinaus die Notwendigkeit, Möglichkeiten und Grenzen gemeinsamer Entscheidungsfindung in komplexen medizinischen Zusammenhängen wie der molekulargenetisch-individualisierten Medizin weiter auszuloten. Und schließlich zeigte sich in den Interviews die Hoffnung auf eine im umfassenden Sinne individualisierte Behandlung.

Schlussfolgerung Damit verdeutlichen die Ergebnisse der Studie die Herausforderung, angesichts stetig zunehmender Möglichkeiten molekulargenetischer Individualisierung auch die psychosozialen Aspekte medizinischer Behandlung angemessen zu berücksichtigen.

\section{Introduction}

In recent years, the hopes and expectations - particularly of patients - associated with so-called individualized medicine (IM) have been the subject of intense debates [1,2]. The primary question is whether and to what extent the expectations of the individual patient that IM will regard him ${ }^{1}$ as an individual are justified. If nothing else, these discussions are the result of the sometimes strongly divergent scientific and medical assessment of the potential of IM. There is one standpoint which believes that comprehensive use of IM would not only make healthcare more effective and efficient, it would also allow care to be adapted to the individual wishes and needs of the respective patient [3-9]. But it has also been suggested that IM is a 'hype' promoted by the economic industrial interests, that its real potential is overrated and, not least, that it raises unrealistic hopes in patients [10-12]: IM is "medicine based on molecular genomic properties and has nothing to do with medicine directed towards the individual patient. Any 'individualization' only occurs at the molecular genomic level, not at a personal level between physician and patient" ([12]: p. 236).

A closer inspection of how the term is actually used shows that IM is generally understood to mean medicine "which attempts to improve the stratification and timing of healthcare provision through the use of biomarkers at the level of the molecular signaling pathways and of genomics, proteomics and metabolomics" ([13]: p. 226, [14, 15]). The statement that IM only individualizes at the molecular genomic level therefore appears to be absolutely correct $[2,16]$.

Nevertheless it is important to have a nuanced view of the potential of IM and its focus on molecular genomics [2,17]. To take a paradigmatic example, gene expression analyses can assist in the decision on adjuvant systemic therapy for patients with breast cancer [18]. The subgroup of patients with primary hormone re- ceptor-positive, HER2-negative breast cancer represents a special case in point: around $80 \%$ of these patients do not require adjuvant chemotherapy to prevent recurrence [19]. The problem is that it is not possible to give clear recommendations for or against adjuvant chemotherapy for this subgroup based on established factors (e.g., patient age or lymph node status) [20]. However, in recent years various genes have been identified, principally in tumor tissue, whose level of expression and activities allow predictive statements to be made about the benefit of adjuvant chemotherapy for these patients. The level of expression and the activities can be investigated using gene expression tests such as Oncotype DX, EndoPredict, Mammaprint or Prosigna, thus - according to the proponents of these tests - providing the basis for reliable therapeutic recommendations [21-25]. While both national and international guidelines recommend performing such tests (www.ago-online.de), the Institute for Quality and Efficiency in Healthcare (IQWiG) has recently stated that the benefits of such strategies are not currently proven [20].

This raises the question whether, given what is actually possible, the hopes and expectation created by molecular genomic individualized medicine, such as the option of avoiding chemotherapy to the benefit of the patient, will not be disappointed. More specifically, the question is whether and to what extent joint decisionmaking by the physician and the patient is even possible given the complex medical-biological mechanisms and the necessity of making each decision on a case-by-case basis. There are a number of empirical studies on the impact of gene expression tests on therapeutic decisions taken by physicians and on potentially con-

Where applicable, the following sections always refer equally to persons of all genders. However, in the interests of readability, only the feminine or masculine form is used, depending on the context. 
flicted decisions by patients [26,27]. But, especially in the context of decisions about adjuvant chemotherapy in patients with primary hormone receptor-positive, HER2-negative breast cancer, there has not been much research into

- how patients perceive such individualized molecular genomic approaches and the therapeutic decisions based on the findings,

- to what extent patients feel that they are involved in the therapy decision, and

- what hopes and expectations they associate with such approaches.

Examining these perspectives is highly important to ensure an ethically appropriate management of the new opportunities created by biomarker-based, stratified medicine, particularly for making autonomous decisions in the context of shared decisionmaking. This study therefore aimed to investigate how well patients with primary hormone receptor-positive, HER2-negative breast cancer understood individualized treatment approaches and to examine patients' hopes and expectations of gene expression analyses, using qualitative explorative interviews.

\section{Material and Methods}

\section{Recruitment}

Patients diagnosed with primary, hormone receptor-positive, HER2-negative breast cancer and who had undergone gene expression analyses as part of adjuvant therapy planning were selected for recruitment into the study. Study participants were recruited by physicians from the Breast Center of Munich University Hospital. Recruitment was done over a period of about one-and-ahalf years. An appointment for an interview was made with those patients who agreed to voluntarily participate in the study and had signed the consent form. All interviews were carried out in the patients' domestic setting. The interview-based study was approved by the Ethics Committee of Ludwig Maximilians University (Project No. 262-13, letter dated July 2, 2013).

\section{Sample}

A sample of eight patients who had been diagnosed with breast cancer between 2013 and 2014 were recruited into the study. All of the interviewed patients were treated in the Breast Center of Munich University Hospital. For 6 patients, the first physician to treat them was a physician from the Breast Center, 2 further patients switched to the Breast Center after they had received their diagnosis. Three patients participated in the ADAPT study [28], 3 other patients participated in the German Breast Cancer Intrinsic Subtype study (BCIST) [27]. Two patients were unable to participate in either of the studies because of diagnostic problems.

At the time of the interview the tumor had been surgically removed in all patients. Adjuvant therapy planning depended on the findings of gene expression analyses. Three patients were undergoing chemotherapy at the time of the interview and had already completed half of their chemotherapy cycles. Three other patients had started radiotherapy. Two patients had undergone breast amputation, which was not followed by further treatment ( $\vee$ Table 1).

\section{Data collection}

Data were collected using guided, partly structured interviews which were carried out in the period from August 2014 to March 2015 by an interviewer who was not part of the treatment team (SS). Questions were devised as open questions to allow the interviewed patients sufficient leeway for their own responses. The interviews were carried out as personal interviews and took between 33 and 55 minutes. Great importance was attached to ensuring that the interview was carried out in a low stress environment.

The interview guidelines were based on the literature and developed after discussion with the relevant experts from the field of oncology; the interviews covered five topics:

1. a description of the patient's medical history,

2. the patient briefing and the decision whether or not to undergo gene expression analyses,

3. how the decision for further treatment was based on gene expression analyses,

4. the patient's perception of the further treatment, and

5. the significance of the findings of gene expression analyses for the patient and third persons.

The interviews were digitally recorded, anonymized and transcribed word for word in accordance with the rules developed by Kuckartz [29].

\section{Data analysis}

The transcripts were analyzed with the help of the MAXQDA 12 software program according to the rules for qualitative content analysis described by Mayring [30]. The goal was to reduce the quantity of existing material to what was essential for the research questions. The first step consisted of developing theory-guided topics for the set of categories. The second step consisted of defining the selection and abstraction criteria for creating the categories. Then, in a third step, inductive main and sub-categories and the characteristics of the individual topic areas were created. The fourth step consisted of defining the categories and providing them with typical examples.

Steps 2 and 3 (determination of selection and abstraction levels, working through the material, formulation of the categories, summarization) was initially done for two interviews and then repeated until the individual categories could be clearly differentiated from one another and the text passages could be unequivocally assigned to categories (step 4). After completing this first processing cycle the categories were applied to the remaining six interviews.

The results of the first four steps were interpreted in a fifth and final step in the light of our research questions and discussed with social science colleagues at a research colloquium. 
- Table 1 Exemplary excerpts from the set of categories: theory-guided topics, deduced main categories and subcategories, typical examples and definitions.

\begin{tabular}{|c|c|c|c|c|c|}
\hline Topics & $\begin{array}{l}\text { Main cate- } \\
\text { gory }\end{array}$ & Subcategory & Variable & Typical example & Definition \\
\hline \multirow[t]{2}{*}{$\begin{array}{l}\text { Understanding } \\
\text { of "individual- } \\
\text { ized medicine" }\end{array}$} & $\begin{array}{l}\text { Perception } \\
\text { of treatment } \\
\text { received }\end{array}$ & $\begin{array}{l}\text { Medical } \\
\text { aspects }\end{array}$ & $\begin{array}{l}\text { Type of } \\
\text { medication }\end{array}$ & $\begin{array}{l}\text { "Everyone is given something else, well I haven't } \\
\text { yet been able to work that out properly yet. } \\
\text { My hubby says a lot but somehow everyone still } \\
\text { seems to be given something else, at least, the } \\
\text { little bags always look different." (RESP 2) }\end{array}$ & $\begin{array}{l}\text { Statement on the extent to } \\
\text { which treatment is perceived } \\
\text { as being tailored to each re- } \\
\text { spective patient (type of medi- } \\
\text { cation, medical treatment) }\end{array}$ \\
\hline & $\begin{array}{l}\text { Reasons for } \\
\text { perception }\end{array}$ & $\begin{array}{l}\text { Choice of } \\
\text { several treat- } \\
\text { ment options }\end{array}$ & & $\begin{array}{l}\text { "The three physicians, that is, the radiologists and } \\
\text { the senior physician, got together and explained } \\
\text { what the options are to me." (RESP 6) }\end{array}$ & $\begin{array}{l}\text { Statements of patients why } \\
\text { they perceived the treatment } \\
\text { as tailored or not tailored to } \\
\text { their needs }\end{array}$ \\
\hline $\begin{array}{l}\text { Perceptions of } \\
\text { gene expres- } \\
\text { sion analyses }\end{array}$ & $\begin{array}{l}\text { Assessment of } \\
\text { gene expres- } \\
\text { sion analyses }\end{array}$ & $\begin{array}{l}\text { Positive } \\
\text { assessment }\end{array}$ & $\begin{array}{l}\text { Appropriate } \\
\text { therapy can } \\
\text { be found }\end{array}$ & $\begin{array}{l}\text { "So when the diagnosis is there, if I can put it that } \\
\text { way, and there is the option of having such tests } \\
\text { before you start treatment to find out how your } \\
\text { body is likely to respond, I think that is a good } \\
\text { option: to find the tailored treatment for yourself. } \\
\text { And not just simply impose a sort of one-type- } \\
\text { fits-all treatment." (RESP 4) }\end{array}$ & $\begin{array}{l}\text { Positive and negative assess- } \\
\text { ment of gene expression } \\
\text { analyses by patients }\end{array}$ \\
\hline \multirow[t]{2}{*}{$\begin{array}{l}\text { Expectations } \\
\text { about the } \\
\text { course of } \\
\text { treatment }\end{array}$} & $\begin{array}{l}\text { Expectations } \\
\text { about the } \\
\text { course of } \\
\text { treatment }\end{array}$ & Schedule & $\begin{array}{l}\text { Near-term } \\
\text { appointments }\end{array}$ & $\begin{array}{l}\text { "And so I got an appointment immediately for the } \\
\text { very next day." (RESP 7) }\end{array}$ & $\begin{array}{l}\text { Statements on the expecta- } \\
\text { tions of patients about the } \\
\text { course of treatment (schedule } \\
\text { and medical procedures, etc.) }\end{array}$ \\
\hline & $\begin{array}{l}\text { Wishes and } \\
\text { suggestions } \\
\text { for improve- } \\
\text { ment }\end{array}$ & $\begin{array}{l}\text { (Psychological) } \\
\text { support for } \\
\text { family } \\
\text { members }\end{array}$ & & $\begin{array}{l}\text { "And I also think, at least that's how I feel, that it } \\
\text { puts a big strain on family members. (...). The kids } \\
\text { aren't stressed that much but my husband, for } \\
\text { example, is really suffering. And I don't know } \\
\text { what could be done to improve matters, so that } \\
\text { they would simply, that they would also be sup- } \\
\text { ported or, yeah." (RESP 5) }\end{array}$ & $\begin{array}{l}\text { Statements on wishes and } \\
\text { suggestions for improvement } \\
\text { made by patients about the } \\
\text { course of treatment }\end{array}$ \\
\hline \multirow[t]{2}{*}{$\begin{array}{l}\text { Involvement in } \\
\text { the patient } \\
\text { briefing and in } \\
\text { the decision } \\
\text { about further } \\
\text { treatment }\end{array}$} & $\begin{array}{l}\text { Developing } \\
\text { the treatment } \\
\text { decision }\end{array}$ & $\begin{array}{l}\text { Making the } \\
\text { decision }\end{array}$ & Patient & $\begin{array}{l}\text { "So then it was my decision, the decision was in } \\
\text { my hands. I was told that if I could live with this } \\
\text { figure of } 13 \% \text {, then we'll only do the radiation, } \\
\text { then you have made the decision. From a medical } \\
\text { perspective we would suggest that you do this } \\
\text { and that." (RESP 4) }\end{array}$ & $\begin{array}{l}\text { Statements on how the deci- } \\
\text { sion for or against a therapy } \\
\text { was made }\end{array}$ \\
\hline & $\begin{array}{l}\text { Patient brief- } \\
\text { ing about gene } \\
\text { expression } \\
\text { analyses }\end{array}$ & $\begin{array}{l}\text { Positive assess- } \\
\text { ment of the } \\
\text { patient brief- } \\
\text { ing received }\end{array}$ & $\begin{array}{l}\text { Explanations of } \\
\text { the Oncotype } \\
\text { DX test by } \\
\text { physicians } \\
\text { were compre- } \\
\text { hensible }\end{array}$ & $\begin{array}{l}\text { "Well I thought to myself that they are doing it } \\
\text { well and they are doing it carefully and that is the } \\
\text { right thing for me now. I was also able to under- } \\
\text { stand how the decision is made." (RESP 5) }\end{array}$ & $\begin{array}{l}\text { Perceptions and information } \\
\text { about gene expression analy- } \\
\text { ses and assessment of the in- } \\
\text { formation }\end{array}$ \\
\hline
\end{tabular}

\section{Results}

Below we present the results for the topic areas "Understanding of individualized medicine", "Perceptions of gene expression analyses", "Expectations about the course of treatment" and "Involvement in the patient briefing and the decision about further treatment" ( $\triangleright$ Table $\mathbf{1}$ ). The sources (RESP) refer to the respective cited respondent.

\section{Understanding of individualized medicine}

Patients were asked about what they understood individualized treatment to mean and whether they perceived gene expression analyses as a part of such a treatment strategy. Seven patients reported that in their view individualized treatment would consist of different treatment options. Chemotherapy, for example, was viewed by these patients as a form of treatment which was often administered regardless of the assessment about its specific benefit and was therefore not considered to be a form of individualized treatment.

During that time I talked with several women [...] They happened to be in hospital in A. The hospital had a kind of general program for these women. And these women also had hormonally active tumors. But no one asked: is that necessary? Does chemotherapy actually offer benefits or are the women suffering more harm than any benefit they could get from it, because chemotherapy does not achieve more than this anti-hormone therapy? (RESP 1) 
Three patients viewed gene expression analyses as part of the diagnostics required for tailored treatment, with drug therapy subsequently tailored to the respective patient and her tumor type. In this context one participant reported that they had found out during talks with other patients that each patient was getting a different drug (RESP 2). Another patient reported that extensive medical tests and examinations had been carried out to confirm her diagnosis and obtain a better assessment of the benefit of further treatment options (RESP 5).

Four patients perceived gene expression analyses as part of stratified treatment, but expressed doubts about whether the treatment really was tailored. They justified their statement by pointing out that it was impossible to administer treatment tailored to every individual person. But they also held the view that there were different types of breast cancer and therefore there were different groups of patients who required different specific drugs.

Well, I think that it is not possible to give tailored treatment to every individual person. [...] But I have the feeling that patients who do have such a hormonally regulated tumor, that they are sort of in the same boat, and that at that moment in time treatment is tailored to me when they say: "okay, in your case, if we can say that the cause is hormonal, then you need surgery and before that anti-hormone therapy, that is where you are at." But that doesn't mean that this only applies to me. I just believe that there are many patients who are in the same boat. And I also think, and that is also what I was told, that I did not get a chemotherapy specially tailored to me but that patients who take the path of anti-hormone treatment, then surgery and then find out that they still have to have chemotherapy, that they get the same drugs, adjusted according to age, blood counts and weight. That's how I would see it. (RESP 4)

The same patient also stated that in her view no tailored therapy existed. She justified her opinion with the statement that for her a tailored therapy would be a treatment with $100 \%$ chance of cure (RESP 4).

\section{Assessment of gene expression analyses}

The assessment of gene expression analyses by patients was generally positive: getting treatment from a hospital which offered such analyses was considered to be an advantage.

And then I just thought: "My God, I am so lucky to have got in there and got the benefit of these new, modern insights." (RESP 1)

In the same context one patient criticized the fact that gene expression analyses were not available in every hospital, partly because treating physicians questioned how useful they were (RESP 8). The interviewed patients primarily justified their positive assessment by the fact that gene expression analyses provided the basis for finding a treatment which was right for them and allowed them to avoid pointless therapies.

So once the diagnosis is there, if I can put it that way, and there is the option of having such tests before you start treatment to find out how your body is likely to respond, I think it is a good option to find the right tailored treatment for yourself. And not just simply impose a sort of one-type-fits-all treatment. (RESP 4)

But patients also criticized gene expression analyses: some patients reported that the findings of the tests were difficult for lay people to understand.

And three, four days later the results were there on a piece of paper. And for the average joe they might as well be written in Chinese. (RESP 4)

A more fundamental criticism was that the test induced hopes which could not be fulfilled. Thus, one patient reported that it had been suggested to her that by carrying out the test she might be able to avoid chemotherapy. The test results had then made it clear that chemotherapy was necessary.

[Because of gene expression analyses, that's right.] It was supposed to find out whether the tumor would respond to hormone treatment, which would actually save me from having to undergo chemotherapy. And the whole time that is what I was assuming, that would be my path, I will not have to do it. And after surgery the values for the tumor which was removed during surgery and the biopsy values were compared with one another. And then I was just told that the values had not dropped to the extent they had hoped. [...] And then I just sat there: will we be doing chemotherapy then? The residual risk without chemotherapy is 13\%. (RESP 4)

Another patient who underwent preventive chemotherapy following the results of gene expression analyses reported that she now had doubts about her decision and that she experienced chemotherapy as extremely debilitating (RESP 8).

\section{Expectations about the course of treatment}

The interviewed patients reported numerous expectations about gene expression analyses and the subsequent treatment based on the analyses, particularly with regard to its timing, the sequence of medical events and the interaction between physician and patient. In addition, a number of suggestions on improving medical and organizational processes were put forward. With regard to timing, all of the patients felt that it was important to not be under time pressure and to have enough time between the diagnosis and the start of therapy to obtain a second opinion if they wished and to get information about the therapy options.

I would say, the first physician was like that, he said to me: "Definitely remove the right breast. Well, there is no other alternative." And they very much suspected that the left side was also affected and he would advise to have my MRI straight away, which would have cost me 600 Euros. And then he gave me something to sign. And then I said: "No, I'm not signing that." So he was a bit affronted. "Why?" [...]. And I said: "Well, I want to look into it first, get myself a second opinion”. (RESP 6)

The patients also expected that the physician would have enough time for them and that decisions for or against a particular ther- 
apy would be made jointly (RESP 5). Most patients wanted to be able to understand the findings of the gene expression tests as this would allow them to assess the potential benefits of further treatment. They therefore expect an extended briefing with a lot of information on the test and an explanation of the analyses results and further treatment options (RESP 4). It was important for them that physicians took enough time, that the physicians' statements were honest and comprehensible, and that the physicians were able to dispel the patient's fears of potential treatment options. One patient stated that she expected the physician to take her opinions seriously and encourage her. After being diagnosed with breast cancer she had deliberately looked for a physician who shared her opinions and her wish to have gene expression analyses (RESP 8).

Another wish of patients related to improving organizational procedures. One patient reported that she would have wished for a coordinator to advise and support patients.

And in terms of registration, what is actually lacking is a person who is there for the patients. Someone whom you could, I guess, call when you say: "Oh, a test." Right, the medical insurance company is not going to pay for that [...]. And then I didn't know how matters were going to continue. That means, should I approach the health insurance company or write a letter to find out whether the health insurance company would still fund it and so on. Something like that, where a coordinator would have that in hand. (RESP 6)

Another patient expressed the wish to receive (psychological) support for her family members.

And I also think, at least that is how I feel, that it puts a big strain on family members. (...). The kids aren't stressed that much, but my husband, for example, is really suffering. And I don't know what could be done to improve matters, so that they would simply, that they would also be supported or, yeah. (RESP 5)

\section{Involvement in the patient briefing and the decision about further treatment}

In response to the question who had given the patient briefing, 6 patients reported that the physician treating them at the Breast Center had informed them about the possibility of having gene expression analyses. Two other patients were not informed by the first physician who treated them about the possibility of having gene expression analyses and only learned about them when they obtained a second opinion or during an extensive internet search (RESP 8).

The majority of patients felt that the briefing about gene expression analyses was largely positive. The interviewed patients reported that they had been given sufficient information about gene expression analyses. They had also generally been able to understand the medical explanations. However, 2 patients reported that, despite the efforts of the physicians, the patients had felt that some of the information about gene expression analyses was too complicated. They ascribed this to the specialist terminology used and to the complexity of gene expression analyses.
In addition to receiving a comprehensible explanation of gene expression analyses the interviewed patients also felt that involving their family and close friends in the patient briefing was important. Some of the patients took family members or people from their circle of friends along to the discussions to ask questions about the information and the resulting treatment options (RESP 6).

The patients were also asked who had taken the decision to have gene expression analyses. Four patients reported that they had taken the decision together with the physician treating them. Two patients had taken the decision to have the test by themselves. Two patients had the impression that the physician treating them had taken the decision for them.

The patients also mentioned various reasons for deciding to have gene expression analyses. All of the patients reported that they had had gene expression analyses in the hope of being able to avoid having chemotherapy.

And then there was also this possibility that I would be able to go on without having chemotherapy. That was really decisive for me. (RESP 5)

Five of the interviewed patients reported in addition that they wanted to take part in the study as it would give them access to the latest medical findings (RESP 1). One patient was encouraged to participate in the study after talking with other breast cancer patients.

And I also talked with patients who had formerly had breast cancer, they said: "Hey, a study program, do it." (RESP 4)

Four of the interviewed patients additionally reported that they hoped that the treatment they would receive after gene expression analyses would be more targeted.

And (...) it is simply the case that the more you know about such a tumor, the more targeted the treatment can be and the more precisely one can say what is now needed and what is not. (RESP 1)

Seven patients reported that they had gene expression analyses because they trusted their physicians and additionally assumed that the physicians would choose the best available options and treatments for them.

Right, so the stuff that I have experienced now from doctors, also in terms of getting information in [hospital], I have such enormous trust, and I know that that is the right path for me. I mean, there is never a guarantee. But there is no guarantee if you have chemotherapy either. But now I just trust that everything is right for me. (RESP 1)

The two patients who were not able to participate in the study reported that they were dissatisfied with the care and treatment they had received from the first physicians who had treated them. This was why they had switched to the Breast Center where physicians offered them the opportunity to have gene expression analyses. 


\section{Discussion}

Given the current discussion about the benefits of gene expression analyses, this study aimed to look at the questions

1. how patients with breast cancer perceived such an individualized molecular genomic approach and the treatment options based on this analyses,

2. to what extent patients felt themselves included in the respective decisions on treatment, and

3. what hopes or expectations patients associated with such an approach.

As regards the first question the study found that the interviewed patients had different perceptions of what gene expression analyses meant in terms of tailored medicine. One patient was of the opinion that no truly tailored treatment existed as this would correspond to treatment with $100 \%$ prospect of cure. This ultimately correct assessment shows what expectations patients associate with the term "tailored" treatment - and how big the risk is of fomenting disproportionate hopes about the absolute certainty of curative therapies, particularly in the context of serious disease.

The other 7 patients (implicitly) differentiated between individualized and tailored treatment strategies: they felt that individualized treatment was primarily distinguished by there being various treatment options while tailored treatment was considered to be drug treatment specifically tailored to the individual patient based on extensive diagnostic tests. Three patients considered gene expression analyses a diagnostic test that would be required for tailored treatment. However 4 patients considered gene expression analyses as a strategy which could be used to differentiate between patient subgroups for which specific therapy options were indicated, with gene expression analyses an important part of stratified molecular genomic medicine. What makes these opinions interesting is that the understanding of individualized treatment strategies falls far short of the claims which are currently being posited for individualized treatment $[2,15]$ and that any type of treatment which includes different therapy options could be referred to as individualized. In contrast, patients' views of tailored medicine appear to mirror the currently prevalent lines of discussion. The fact that 3 of the interviewed patients understood gene expression analyses to be part of a treatment strategy aimed at the individual patient shows that the treatment concept is likely to raise false hopes among some of the patients. The patients who understood gene expression analyses as one element of stratified therapeutic treatment had a far more realistic view and one which corresponded more closely to the developments which are currently being promoted under the label of individualized medicine $[14,15]$.

Despite the differences in their understanding of individualized or tailored medicine outlined above, what was very striking was the overwhelmingly positive perception of gene expression analyses and of the decisions based on the test outcomes: the analyses could be used to select the appropriate treatment option for each respective patient and avoid unnecessary treatment. The understanding of tailored treatment strategies therefore played, at best, a minor role in the retrospective assessment of the treatment they had received. What was more important was that gene ex- pression analyses helped patients underpin their certainty about their own subjective decision for or against treatment options. This was also noted in other studies $[26,27]$. It was due to patients' clearly expressed expectation of getting better treatment following gene expression analyses, either because treatment would be more targeted and therefore more effective or because gene expression analyses would allow them to avoid having to undergo debilitating therapy with many side effects and no potential benefits. But these expectations can only be fulfilled if reliable information on the potential benefits and risks of biomarkerbased, stratified treatment strategies is available [10].

Only one patient criticized that it had been suggested to her that by carrying out gene expression analyses she could avoid chemotherapy - which had not been the case. The statements of this interviewed patient indicated that she had erroneously assumed that there was a causal connection between gene expression analyses tests and avoiding chemotherapy, i.e., she had assumed that the analyses themselves would be enough for her not have to have chemotherapy. This misunderstanding points to our second research question about the perception of being involved in therapeutic decisions and, in this connection, about the perceptions of how patients had been briefed by physicians about gene expression analyses and the therapy decisions based on the analyses.

Although the patients largely rated the briefing and information they had received as positive, two of the interviewed women emphasized that the medical information was difficult for lay people to understand and that the explanations were too complicated. Nevertheless, all of the patients stated that they wanted to hear the results of the gene expression analyses so that they could assess their therapy options and make a decision together with their physician. Several studies have shown that there is an increasing tendency for patients with breast cancer to participate actively in therapy decisions [31-33]. One study which looked at the Prosigna test showed that patients with breast cancer who were given the results of their gene expression tests were indeed better informed and more able to participate in decision-making and that their emotional and functional well-being was higher [27]. But what was striking in our study was that only 4 patients reported that they had really decided together with their treating physician about their further course of treatment. In contrast, 2 patients stated that they had taken the decision alone and 2 suggested that the decision for a specific treatment had only been taken by the physicians. These statements emphasized the need to further explore the opportunities and limits to joint decisionmaking in complex medical contexts such as individualized molecular genomic medicine. But it is also conceivable that the different assessments may conceal different preferences with respect to the patient's own role in the decision-making process.

As regards our third research question, in addition to the opportunity of joint decision-making the interviewed women expressed a number of other hopes and expectations about treatment decisions based on gene expression analyses: key expectations included the hope that patient's individual needs would be taken into account during treatment. Several patients also wished for structured counseling for themselves and family members. These statements show that the interviewed patients expected far more than just differentiated molecular genomic treatment, i.e., that 
they wished for individualized treatment in the broadest sense of the term, treatment which would take patients seriously as individual personalities. Ideally, as one patient hoped, the treating physician would be of the same opinion as his patient with regard to existing treatment options. Given the plurality of values and attitudes to life which exist in modern society this ideal will only rarely be achieved. Instead the ethical requirement must be that the physician is open to the different needs of his patient and supports his patient in choosing the type of treatment which is most appropriate for the patient's individual situation and attitude to life. But patients also need enough time to get a second opinion if they want it, and to be supported by a person they trust. This study once again highlights the challenge of taking psychosocial aspects sufficiently into account during medical treatment, given the ever increasing options of molecular genomic individualization [16]; it is the only way in which so-called individualized medicine can fulfil what patients rightly expect: that their medical treatment will be patient-oriented in the broadest sense of the word.

Finally it should be noted that this empirical study has several methodological limitations which need to be taken into account when interpreting the results. One limitation of the study is its small sample size. Despite intensive efforts and the involvement of a gatekeeper only 8 patients could be recruited into the study over a period of 1.5 years. This is probably due to the sensitive topic of the analysis and the expected associated stress for study participants, particularly in the immediate postoperative phase. It would therefore be useful to carry out further studies into the perception and assessment of individualized medical approaches such as diagnostic gene expression analyses. As this study only interviewed patients who had individualized treatment, future studies could focus on interviewing patients who underwent standard treatment. This would allow the perception and assessment of both treatment options to be compared, which would provide further insight into treatment options from the patients' point of view. Similarly, the results of this explorative study could contribute to developing the appropriate quantitative survey instruments.

A further limitation lies in the sample population itself. Most of the patients who participated in the study were satisfied with the process and implementation of gene expression analyses testing and therefore had a positive view of gene expression analyses. Only one patient had retrospective doubts about her decision.

Danksagung

This study was carried out as part of the research project "Individualized Healthcare: Ethical, Economic and Legal Implications for the German Healthcare System" (FKZ 01GP1006) supported by the German Federal Ministry of Education and Research. We would like to thank Orsolya Friedrich, Ralf Jox, Katja Kühlmeyer, Johannes Kögel and Oliver Rauprich for their comments on the content and methodology of an earlier version and Brigitte Ehrl for her help in recruiting participants to the study.

\section{Conflict of Interest}

SS, ST and GM report that they have no conflict of interest. RW is a consultant for Agendia, Genomic Health and Nanostring.

\section{References}

[1] Collins FS. The Language of Life. DNA and the Revolution in personalized Medicine. New York: HarperCollins; 2010

[2] Schildmann J, Vollmann J. Personalized Medicine: conceptual, ethical, and empirical Challenges. In: Schramme T, Edwards S, eds. Handbook of the Philosophy of Medicine. Vol. 2. Berlin: Springer; 2017: 903-913

[3] Snyderman R, Williams RS. Prospective medicine: the next health care transformation. Acad Med 2003; 78: 1079-1084

[4] Gorini A, Pravettoni G. P5 medicine: a plus for a personalized approach to oncology. Nat Rev Clin Oncol 2011; 8: 444

[5] Pravettoni G, Gorini A. A P5 cancer medicine approach: why personalized medicine cannot ignore psychology. J Eval Clin Pract 2011; 17: 594-596

[6] Burnette R, Simmons LA, Snyderman R. Personalized health care as a pathway for the adoption of genomic medicine. J Personalized Med 2012; 2: 232-240

[7] Cornetta K, Brown CG. Perspective: balancing personalized medicine and personalized care. Acad Med 2013; 88: 309

[8] Horwitz RI, Cullen MR, Abell J et al. (De)personalized medicine. Science 2013; 339: 1155-1156

[9] Heusser P. Towards Integration of personalised and 'person-centred' Medicine: The Concept of 'integrative and personalised Health Care'. In: Vollmann J, Sandow V, Wäscher S, Schildmann J, eds. The Ethics of personalised Medicine. Farnham: Ashgate; 2015: 77-84

[10] Ludwig WD. Möglichkeiten und Grenzen der stratifizierenden Medizin am Beispiel von prädiktiven Biomarkern und, „zielgerichteten“' medikamentösen Therapien in der Onkologie. ZEFQ 2012; 106: 11-22

[11] Vollmann J. Ein trügerisches Versprechen. Frankf Allg Ztg 2012; $105: 10$

[12] Vollmann J. Persönlicher - besser - kostengünstiger? Kritische medizinethische Anfragen an die „personalisierte Medizin“. Ethik Med 2013; 25: 233-241

[13] Schleidgen S, Marckmann G. Alter Wein in neuen Schläuchen? Ethische Implikationen der Individualisierten Medizin. Ethik Med 2013; 25: 223 231

[14] Schleidgen S, Klingler C, Bertram T et al. What is personalized medicine? Sharpening a vague term based on a systematic literature review. BMC Med Eth 2013; 14: 55

[15] Langanke M, Lieb W, Erdmann P et al. Was ist Individualisierte Medizin? Zur terminologischen Justierung eines schillernden Begriffs. ZME 2012; 58: 295-314

[16] Schleidgen S. Individualisieren durch technisieren? Anmerkungen zur Biomarker-basierten Medizin. In: Aurenque D, Friedrich O, Hrsg. Medizinphilosophie oder philosophische Medizin? Philosophisch-ethische Beiträge zu Herausforderungen technisierter Medizin. Stuttgart: Frommann-Holzboog; 2013: 265-285

[17] Browmann G, Virani A, Vollmann J et al. Improving the quality of 'personalized medicine' research and practice through an ethical lens. Pers Med 2014; 11: 413-423

[18] Kreienberg R, Albert U, Follmann M et al. Interdisziplinäre S3-Leitlinie für die Diagnostik, Therapie und Nachsorge des Mammakarzinoms: Kurzversion 3.0. Online: http://www.awmf.org/uploads/tx_szleitlinien/ 032-045OL_k_S3_Brustkrebs_Mammakarzinom_Diagnostik_Therapie _Nachsorge_2012-07.pdf; last access: 04.05.2017 
[19] Wolters R, Wockel A, Wischnewsky M et al. Auswirkungen leitlinienkonformer Therapie auf das Überleben von Patientinnen mit primärem Mammakarzinom: Ergebnisse einer retrospektiven Kohortenstudie. Z Evid Fortbild Qual Gesundhwes 2011; 105: 468-475

[20] Institut für Qualität und Wirtschaftlichkeit im Gesundheitswesen. Biomarkerbasierte Tests zur Entscheidung für oder gegen eine adjuvante systemische Chemotherapie beim primären Mammakarzinom. IQWiGBerichte - Nr.457. Online: https://www.iqwig.de/download/ D14-01_Abschlussbericht_Biomarker-bei-Mammakarzinom.pdf; last access: 04.05 .2017

[21] Paik S, Shak S, Tang G et al. A multigene assay to predict recurrence of tamoxifen-treated, node-negative breast cancer. N Engl J Med 2004; 351: 2817-2826

[22] Paik S, Tang G, Shak S et al. Gene expression and benefit of chemotherapy in women with node-negative, estrogen receptor-positive breast cancer. J Clin Oncol 2006; 24: 3726-3734

[23] Knauer M, Mook S, Rutgers EJT et al. The predictive value of the 70-gene signature for adjuvant chemotherapy in early breast cancer. Breast Cancer Res Treat 2010; 120: 655-661

[24] Dowsett M, Sestak I, Lopez-Knowles E et al. Comparison of PAM50 risk of recurrence score with oncotype DX and IHC4 for predicting risk of distant recurrence after endocrine therapy. J Clin Oncol 2013; 31: 27832790

[25] Degenhardt T, Harbeck N, Wuerstlein R. Individuelle Tumortherapie beim Mammakarzinom - Möglichkeiten der Vermeidung von Über- und Untertherapie unter besonderer Berücksichtigung zielgerichteter Therapien. DZO 2015; 47: 57-65
[26] Eiermann W, Rezai M, Kümmel S et al. The 21-gene recurrence score assay impacts adjuvant therapy recommendations for ER-positive, nodenegative and node-positive early breast cancer resulting in a riskadapted change in chemotherapy use. Ann Oncol 2013; 24: 618-624

[27] Wuerstlein R, Sotlar K, Gluz O et al. The West German Study Group Breast Cancer Intrinsic Subtype study: a prospective multicenter decision impact study utilizing the Prosigna assay for adjuvant treatment decision-making in estrogen-receptor-positive, HER2-negative early-stage breast cancer. CMRO 2016; 32: 1217-1224

[28] Harbeck N, Wuerstlein R. Mammakarzinom. Individualisierte Therapiekonzepte. Internist 2013; 54: 154-200

[29] Kuckartz U. Qualitative Evaluation. Der Einstieg in die Praxis. Wiesbaden: VS Verlag für Sozialwissenschaften; 2007

[30] Mayring P. Qualitative Inhaltsanalyse. Grundlagen und Techniken. Weinheim und Basel: Beltz; 2010

[31] Singh JA, Sloan JA, Atherton PJ et al. Preferred roles in treatment decision making among patients with cancer: a pooled analysis of studies using the control preferences scale. Am J Manag Care 2010; 16: 688-696

[32] Tariman JD, Berry DL, Cochrane B et al. Preferred and actual participation roles during health care decision making in persons with cancer: a systematic review. Ann Oncol 2010; 21: 1145-1151

[33] Brown R, Butow P, Wilson-Genderson M et al. Meeting the decision-making preferences of patients with breast cancer in oncology consultations: impact on decision-related outcomes. J Clin Oncol 2012; 30: 857-862 